\title{
Influence of Organizational Culture, Job Satisfaction, and Work Motivation to The Commitment of The Organization of Primary School Teachers of The Sub District Sumbul Pegagan District Dairi
}

\author{
Romaulina Siburian ${ }^{1}$, Paningkat Siburian ${ }^{2}$, Khairil Ansari $^{3}$ \\ Education Administration Study Program ${ }^{1}$, State University of Medan, Indonesia 2,3 \\ ulina211989@gmail.com
}

\begin{abstract}
This research aims to describe and know (1) The influence of organizational culture to work satisfaction, (2) influence of organizational culture to the motivation of work, (3) influence of organizational culture to organizational commitment, (4) influence Job satisfaction of organizational commitment, and (4) effect of work motivation to the commitment of the state elementary school teacher in Sumbul Pegagan District Dairi. The type of research used is quantitative research with pathway analysis approach. The sample amount amounted to 187 people with sampling techniques using proportional random sampling. Research instrument in the form of poll, before the hypothesis testing conducted test analysis requirements, namely the test of data normality with Lily flowers, the test of linearity and the sense of regression with the analysis of variances on the level of $\alpha$ significance of 0.05 . The results of the study found: (1) The organizational culture directly influence positively to job satisfaction, (2) The organizational culture of direct influence positively towards the motivation of work, (3) The organizational culture of direct influence positively to the commitment Teacher organizations, (4) Positive direct impact work satisfaction towards teacher organization commitments, (5) motivation of working positive direct influence on teacher's organizational commitments. The higher the influence of organizational culture, job satisfaction and the motivation of the teacher's work, the higher the commitment of the organization of elementary school teachers in Sumbul Pegagan District Dairi.
\end{abstract}

Keywords: Organizational Commitment, Organizational Culture, Job Satisfaction, Work Motivation

\section{Introduction}

Educational institutions are places to provide knowledge, develop skills and shape one's attitude. School is a place where the educational process takes place and is commonly called the teaching and learning process, where the process is expected to achieve educational goals, including equipping students to have three domains (cognitive, affective and psychomotor), so that students will later become human resources reliable and responsible in the midst of society, nation and state. This is where the role of schools becomes an important institution for the growth and development of individuals and communities. 
Law of the Republic of Indonesia Number 14 of 2005 concerning teachers and Lecturers article 7 explains that the teaching profession is a special work carried out based on the principle of having a commitment to improve the quality of education, faith, piety and noble character. Professional teachers must have work commitments, academic qualifications, competencies, and responsibilities required as a basis for being able to carry out their work effectively and efficiently.

Regarding professional teachers in Indonesia, various efforts have been made to improve the quality of teachers in order to implement the national education system and realize national education goals. The education certification program through Teacher Professional Education and Training (PLPG) activities along with the provision of professional allowances, training, training, seminars and further education through the Educational Undergraduate Program for Teachers in office (PSKGJ) or through program 1 to several universities is as an effort has been and is being done to turn teachers into professional staff who have good competence, strong organizational commitment, high job satisfaction, work motivation and strong organizational culture. Thus, teachers as learners are expected to be able to carry out their duties and functions properly in realizing national education goals.

Based on these data the focus of the discussion in this paper is about "how The Effect of Organizational Culture, Job Satisfaction and Job Motivation on Organizational Commitment Teacher of State Elementary in regional incitement District Dairi".

Luthans [1] states the organizational commitment as attitude is: (1) Commitment comes from the word commit. Echols [2] states, commitment means to do, then commitment means to make promises and responsibilities. Commitment is the decision of someone with himself, whether he will do an activity. Commitment is an attitude because it is a reflex of one's feelings (like or dislike) towards the organization in which the individual works. Robbins' opinion emphasizes commitment as a work attitude or belief that reflects the strength, personality and involvement of individuals in an organization. Commitment is the decision of someone with himself, whether he will do some activity, the strong desire to remain as a member of the organization; (2) the desire to strive according to the wishes of the organization; and (3) certain beliefs and acceptance of the values and goals of school organizations. Colquitt, LePine, Wesson [3] argues that organizational commitment includes effective commitment influenced by organizational culture, leadership styles \& behavior, personality and cultural values (personality $\&$ culture) values), and motivation (motivation).

Organizational commitment is degree to which employees believe in and accept organizational goals and desire to remain with the organization Mayer \& Allen in [4] said organizational commitment is a condition in which a particular employee sits on a particular organization and its purpose and desire to maintain membership in the organization. Organizational culture according to Colquitt, LePine, Wesson [3] is a shared social knowledge in an organization about rules, norms, and values that shape employee attitudes and behavior. This definition helps highlight a number of aspects of organizational culture. First, culture is social knowledge among members of the organization. Employees learn about the most important aspects of culture through other employees. Second, culture tells employees what the organization's rules, norms, and values are. What is the most important work outcome is to focus. Third, organizational culture shapes and reinforces certain employee attitudes and behaviors by creating a system of control over employees.

Job Satisfaction According to Colquitt, LePine, Wesson [3] job satisfaction is the level of pleasant feelings obtained from the assessment of one's work or work experience. In other words job satisfaction reflects how we feel about our work and what we think about our work. Job satisfaction is a positive feeling about work as a result of evaluating its characteristics. 
Wahjosumidjo [5] provides states motivation can be interpreted as a psychological process that reflects the interaction between attitudes, needs, perceptions, and satisfaction that occurs in a person.

\section{Research Method}

This research was conducted using quantitative methods. The model used is a path analysis model (path analysis) or often referred to as a pattern of cause and effect relationships. According to Riduwan and Kuncoro [6] path analysis is used to analyze the pattern of relationships between variables in order to determine the direct or indirect influence of a set of independent (exogenous) variables on the dependent variable (endogenous).

This research was conducted at the SD Negeri Sumbul Subdistrict, Dairi Regency. Which was carried out in September 2019. In this study, the population was all elementary school teachers in Sumbul Subdistrict, Dairi Regency, spread in 37 schools totaling 349 people. Researchers took the number of samples using the Slovin formula with a chance of error or significance level $\alpha=0.05$ with a sample of 187 people. The research sampling technique used is proportional random sampling. The data collection in this study used a questionnaire of organizational commitment, organizational culture, job satisfaction, and achievement motivation in the form of a Likert scale.

\section{Result and Discussion}

This study has four variables and the results of data collection and analysis can be described as follows.

a) Correlation Between X1 Variable with Variable X2

From distribution list $\mathrm{t}$ with $\mathrm{df}=187$ and the level of significance $5 \%$ is obtained this $=$ 1.653. Thus, it turns out that $t_{h}>$ this $(2.618>1.653)$ so that it can be concluded that there is no meaningful correlation between variables of the X1 variable with X2.

b) Correlation Between X1 Variables with X3 Variables

From distribution list $\mathrm{t}$ with $\mathrm{df}=187$ and the level of significance $5 \%$ is obtained this $=$ 1.653. Thus, it turns out that $t_{h}>$ this $(4.430>1.653)$ so that it can be concluded that there is a meaningful correlation between variable $\mathrm{X} 1$ variables with $\mathrm{X} 3$

c) Correlation Between X1 Variable With X4 Variable From distribution list $\mathrm{t}$ with $\mathrm{df}=187$ and the level of significance $5 \%$ is obtained this $=$ 1.653. Thus, it turns out that $t_{h}>$ this $(4.139>1.653)$ so that it can be concluded that there is a meaningful correlation between variable $\mathrm{X} 1$ variable with $\mathrm{X} 4$

d) Correlation Between The Variable X2 With The X3 Variable From distribution list $\mathrm{t}$ with $\mathrm{df}=187$ and the level of significance $5 \%$ is obtained this $=$ 1.653. Thus, it turns out that $t_{h}>$ this $(3.797>1.653)$ so that it can be concluded that there is no meaningful correlation between variable $\mathrm{X} 2$ variables with $\mathrm{X} 3$

e) Correlation Between Variable X2 And X4 Variables 
From distribution list $\mathrm{t}$ with $\mathrm{df}=187$ and the level of significance $5 \%$ is obtained this $=$ 1.653 . Thus, it turns out that the $<$ this $(5.037<1.653) \mathrm{t}_{\mathrm{h}}$ so it can be concluded that there is a meaningful correlation between variable $\mathrm{X} 2$ variables with $\mathrm{X} 4$.

f) Correlation Between X3 Variable with X4 Variable

From distribution list $\mathrm{t}$ with $\mathrm{df}=187$ and the level of significance $5 \%$ is obtained this $=$ 1.653. Thus, it turns out that $t_{h}>$ this $(4.913>1.653)$ so that it can be concluded that there is no meaningful correlation between variable $\mathrm{X} 3$ variables with $\mathrm{X} 4$.

\section{Hypothesis 1}

The proposed hypothesis is: H0: P21 = 0: The culture of the Organization has a direct effect on the work satisfaction of the state elementary school teacher Sumbul, Dairi district. H0: P21 $\neq 0$ : Culture of organization does not directly affect the positive work satisfaction of elementary school teachers in Sumbul district, Dairi District. Further to know the significance of the analysis of the path, then compared between the probability value 0.05 with a Sig value with the basis of decision making as follows if the probability value $(0.05<\mathrm{Sig})$ then Ho accepted and Ha rejected, the meaning is not significant. If the value of probability $(0.05>\mathrm{Sig})$ then Ho is rejected and Ha accepted, it means significant.

For the hypothesis test seen in the Sig column (significant) in table 4:16 Coefficients obtained the value of Sig $0.00(0.05>0.00)$, then Ho rejected and Ha accepted means the organizational culture directly affects the satisfaction of work. It means that the hypothesis is proposed that the task commitment directly affect work satisfaction is acceptable.

\section{Hypothesis 2}

The proposed hypothesis is H0: P31 = 0: The culture of the Organization has a direct effect on the motivation to work of elementary school teachers in Sumbul district, Dairi District. H0: P31 $\neq 0$ : Culture of organization does not directly affect the positive working motivation of elementary school teachers in Sumbul district, Dairi District. Further to know the significance of the analysis of the path, then compared between the probability value 0.05 with a Sig value with the basis of decision making as follows if the probability value $(0.05<\mathrm{Sig})$ then Ho accepted and Ha rejected, the meaning is not significant. If the value of probability $(0.05>\mathrm{Sig})$ then Ho is rejected and Ha accepted, it means significant.

To test the hypotheses seen in the field of GIS (significant) in table 4:16 Coefficients obtained the value of Sig $0.00(0.05>0.00)$, then Ho rejected and Ha accepted means that the organizational culture directly affects the motivation of work. It means that the hypothesis is proposed that the organizational culture directly affects the motivation of work acceptable.

\section{Hypothesis 3}

The proposed hypothesis was H0: $\mathrm{P} 41=0$ : The culture of the organization has direct effect on the commitment of the organization of elementary school teachers in Sumbul district of Dairi District. H0: P41 $\neq 0$ : Culture of organization has no direct effect on the commitment of the organization of elementary school teachers in Sumbul district Dairi. Further to know the significance of the analysis of the path, then compared between the probability value 0.05 with a Sig value with the basis of decision making as follows if the probability value $(0.05<\mathrm{Sig})$ then Ho accepted and Ha rejected, the meaning is not significant. If the value of probability $(0.05>\mathrm{Sig})$ then Ho is rejected and Ha accepted, it means significant.

For the hypothesis test seen in the Sig column (significant) in table 4:16 Coefficients obtained the value of Sig $0.00(0.05>0.00)$, then Ho rejected and Ha accepted means that the 
organizational culture directly affects the commitment of the Organization. It means that the hypothesis is proposed that the organizational culture directly affects the organizational commitments acceptable.

\section{Hypothesis 4}

The proposed hypothesis is Ho: $\mathrm{P} 42=0$ : Job satisfaction has a direct positive impact on the commitment of the state elementary school teacher in Sumbul, Dairi district. H0: P42 $\neq 0$ : Job satisfaction has no direct positive effect on the commitment of the state elementary school teacher Sumbul District Dairi. Further to know the significance of the analysis of the path, then compared between the probability value 0.05 with a Sig value with the basis of decision making as follows if the probability value $(0.05<\mathrm{Sig})$ then Ho accepted and Ha rejected, the meaning is not significant. If the value of probability $(0.05>\mathrm{Sig})$ then Ho is rejected and Ha accepted, it means significant.

To test the hypotheses seen in the field of GIS (significant) in table 4:16 Coefficients obtained the value of Sig $0.00(0.05>0.00)$, then Ho rejected and Ha acceptable means that the satisfaction of the work directly affects the commitment of the Organization. It means that the hypothesis is proposed that work satisfaction directly affects the organizational commitments are acceptable.

\section{Hypothesis 5}

The proposed hypothesis is $\mathrm{H} 0$ : $\mathrm{P} 53=0$ : The motivation of work has a direct positive impact on the commitment of the state elementary school teacher in Sumbul District, Dairi District. H0: P53 $\neq 0$ : Work motivation has no direct positive effect on the commitment of the state elementary school teacher Sumbul District Dairi. Further to know the significance of the analysis of the path, then compared between the probability value 0.05 with a Sig value with the basis of decision making as follows if the probability value $(0.05<\mathrm{Sig})$ then Ho accepted and $\mathrm{Ha}$ rejected, the meaning is not significant. If the value of probability $(0.05>\mathrm{Sig})$ then Ho is rejected and Ha accepted, it means significant.

To test the hypotheses seen in the field of GIS (significant) in table 4:16 Coefficients obtained the value of Sig $0.00(0.05>0.00)$, then Ho rejected and Ha acceptable means that the motivation of work directly affects the commitment of the Organization. It means that the hypothesis is proposed that the motivation of work directly affects the organizational commitments are acceptable.

\section{Conclusion}

Based on the results of the study as described in chapter $\mathrm{v}$, the following research findings are summarized: a) Organizational culture has a direct positive effect on job satisfaction of elementary school teachers in Sumbul sub-district, Dairi district. In other words, the stronger the organizational culture, the greater the job satisfaction of elementary school teachers in Sumbul sub-district, Dairi district; b) Organizational culture has a direct positive effect on the work motivation of elementary school teachers in Sumbul Subdistrict, Dairi Regency. In other words, the stronger the organizational culture, the higher the work motivation of elementary school teachers in Sumbul Subdistrict, Dairi Regency; c) Organizational culture has a direct positive effect on the commitment of elementary school teacher organizations in Sumbul Subdistrict, Dairi Regency. In other words, the stronger the organizational culture, the higher 
the commitment of the elementary teacher organization in Sumbul Subdistrict, Dairi Regency; d) Job satisfaction has a direct positive effect on the commitment of elementary school teacher organizations in Sumbul Subdistrict, Dairi Regency. In other words, the higher the job satisfaction, the stronger the commitment of the elementary teacher organization in Sumbul Subdistrict, Dairi Regency; e) Work motivation has a direct positive effect on the commitment of elementary school teacher organizations in Sumbul Subdistrict, Dairi Regency. In other words, the higher the work motivation, the stronger the commitment of the elementary teacher organization in Sumbul Subdistrict, Dairi Regency.

\section{References}

[1] Luthans, Fred. Perilaku Organisasi: terjemahan. Vivin Andika Ywono, et all., Yogyakarta. (2006)

[2] Echols, J. M. Kamus Inggris Indonesia. Jakarta: Gramedia.Robbins, S. P. 2007. Perilaku Organisasi. Edisi Kesepuluh Alih Bahasa: Benyamin Bolan. Jakarta: Jaya Cemerlang. (2003)

[3] Colquitt., J. A., Lepine, J. A., Wesson, M. J. Organizational Behavior, Improving Performance and Commitment in the Workplace. New York: McGraw-Hill. (2009)

[4] Wirawan. Kepemimpinan: Teori, Psikologi, Perilaku Organisasi, Aplikasi, dan Penelitian. Jakarta: Raja Grafindo Persada. (2014)

[5] Wahjosumidjo. Kepemimpinan dan Motivasi. Jakarta: Ghalia Indonesia. (2001)

[6] Riduwan, dan Engkos Achmad Kuncoro. 2010. Cara Menggunakan dan Memakai Path Analysis. Bandung: Alfabeta. (2010) 